\title{
ENGLISH REMAINS MORE EQUAL THAN OTHER LANGUAGES AND CONTINUES TO COLONISE THE CLASSROOM: ACCOUNTING TEACHERS PERSPECTIVES IN SOUTH AFRICA
}

\author{
Dr Motalenyane Alfred Modise, Dr Segalo Letlhonyo and Molefi Motsoeneng \\ Department of Language and Social Science Education, Central University of Technology, Free \\ State, South Africa, mamodise@cut.ac.za,057-9103631
}

\begin{abstract}
South Africa has eleven official languages and learners are initially taught in their mother tongue (from Grades 1 to 3 ) and most subsequent teaching takes place in English or Afrikaans and it creates a problem to most learners. The aim of this study is to probe into the impact of English as the language of learning for Limited English Proficiency (LEP) Grade 10 Accounting learners in Free State Province, South Africa. The study used the qualitative approach and utulised the phenomenological gain an in-depth understanding of the Accounting teacher's perspective about the challenges faced by LEP Accounting learners in South Africa and how to address their problems in South African schools. Participants comprised of a purposive sample of 30 Accounting teachers (male:8, female:12, age 20-36). Data on challenges faced by LEP Accounting learners were collected using semi-structured individual interviews. The study revealed that LEP Accounting learners struggle to understand the language used in the Accounting question because they are not comfortable with the language. The study also asserted that basic Accounting equation as the basic for Accounting learners is a challenge to LEP Accounting. The further indicated that LEP Accounting learners struggle junk Accounting concepts because they are not in their mother. The South African need to implement their policies to address the imbalances of the past and mother tongue must be implemented in schools to address the challenges faced by LEP Accounting learners in South Africa and development of accounting concepts in African languages must be encouraged.
\end{abstract}

Keywords: Accounting, Limited English proficiency, Participation, Accounting, Concepts

\section{INTRODUCTION}

Language issues have long been an area of consideration and sensitivity in the context of South African Education. Limited English Proficiency (LEP) of learners is one of the most pressing of these language issues. English language proficiency among young South Africans for whom English is not their mother tongue is low (Monyai, 2010). In this study, the researcher will investigate the effects of English as the language of learning for LEP Grade 10 Accounting learners, identify the problems that influence their learning through English, and provide a strategy aiming to address this long-standing problem in South Africa.

Since South Africa became a democracy in 1994, the South African education system has been engaged in a process of transformation. This transformation has affected all areas of the education system, including 
curriculum development and implementation, governance and management. Outcomes-Based Education $(\mathrm{OBE})$, emphasising a learner-centred approach, formed the foundation of the original Curriculum 2005 in South Africa. The National Curriculum Statement (NCS) was introduced from Grade 10-12 during 2003, followed by the Revised National Curriculum Statement (RNCS) and, more recently, the Curriculum and Assessment Policy Statement (CAPS). Accounting is included in the CAPS at Grade 10 level and is taught to many learners who demonstrate LEP (Department of Basic Education (DBE), 2011).

When South Africa became a Union as part of the British Empire in 1910, the language of government, schools, the legal system and business became English. Changes in education language policy again occurred after the National Party came to power in 1948. Currently South Africa has 11 official languages, but, without exception, most people opt for English as the lingua franca (Ferreira, 2011). Most South Africans can speak more than one of the official languages: isiZulu, isiXhosa, Sepedi (referring to Northern Sotho), Setswana, English, Afrikaans, Sesotho (referring to Southern Sotho), Xitshonga, Siswati, Tshivenda and isiNdebele (referring to Southern Ndebele) (Ferreira, 2011).

Wright and Bilica (2007) explain that modern educational theory, as evidenced in the conceptual change learning model, internationally encourages Accounting teachers to focus less on fact-based, rote-learning and more on conceptually driven teaching. This requires teachers to plan teaching by first getting information about learners' prior knowledge and then using this to structure lessons. Ellis (2012) further proposes that besides learners' prior knowledge and experiences, language and interpersonal relations between teachers and learners in the classroom are necessary for successful learning. Consequently, language plays an important role in the teaching and learning of Accounting.

\section{METHOD}

The study utilized a phenomenological qualitative inquiry (Ary, Jacobs, Razavieh and Sorensen, 2009) to gain an in-depth understanding of both challenges faced by LEP Accounting learners in South Africa and how to address. The phenomenological approach is appropriate for studies which have the goal of exploring people's actual social experiences - in this case Accounting in South Africa

\section{PARTICIPANTS AND SETTING}

Participants were a convenience sample of 30 Accounting teachers (male $=8$, female 12, age 20- 26 years) in the Free State Province of South Africa. The participants were mainly black, Setswana, Sesotho, Afrikaans and Xhosa speaking teachers from rural Free State communities

\section{DATA COLLECTION AND PROCEDURE}

Participating students completed a semi-structured individual interview on their perception of LEP Accounting learners in South Africa. Approval to conduct research was granted by the participants, who completed consent forms as individuals in the Free State Province, South Africa. For ethical reasons, the names of respondents were not identified.

\section{DATA ANALYSIS}

Data was thematically analysed using open-coding procedures (Hesse-Biber and Leavy, 2010). These involved systematically organizing, categorizing and summarizing data and describing it in meaningful themes. Themes were assigned codes to condense the data into categories.

\section{FINDINGS AND DISCUSSION}

The thematic analysis resulted in the following aspects of LEP Accounting in South Africa and the following themes were discussed: (i) Language use in Accounting question papers, (ii) Understanding Accounting Equation concepts and ( iii) Year-end adjustments concepts

\section{THEME}

\subsection{Theme1: Language Use In Accounting Question Papers}

Participants stated that difficult concepts and terms are used in the question papers, therefore they often struggle to analyse and answer such questions. They claimed that they sometimes come across unfamiliar terms in the examination papers they have not encountered before. This cause confusion and frustration when they are not sure what such terms mean. Participant \#3, female: "I find difficult to analysis the transaction, especially the adjustments with big terms and difficult English, other concepts are new to us in the examination". 
In addition, some indicated that they sometimes ask invigilators during the examination to interpret certain concepts for them. They further mentioned that the interpretations are not always correct, but that they are prepared to take such a chance in order to have some idea of what to answer. Participant \#8, male: "I struggle to answer the Accounting examination because of the difficult words or terms in the question papers, then I ask help from the invigilator, sometimes that is wrong interpretation of question and lead to wrong answers".

Adding to the problem, all of them claimed that in the classroom they use English, Sesotho and Setswana to understand Accounting and in the examination English is compulsory. The participants said that sometimes they know something in Sesotho, Setswana or IsiXhosa, but find it difficult to write in English. They claimed that reading is a problem because sometimes they cannot analyse and interpret the transactions correctly because of the difficult concepts in the examination paper. Participant \#7, female: "I struggle a lot, sometime I know something in Sesotho but I cannot write it in English, I cannot read".

Participants claimed that they simply guess answers and seem to show little understanding of concepts taught. Also, some learners did not read questions and did not appear to understand an instruction, which meant that they were unable to apply what knowledge they did have when they attempted to answer questions. Participant \#12, male: "It is difficult to understand the questions and terms instructions are not easy in the question paper and answering questions is not easy".

Interpretation: Participants cannot read and understand English correctly; words used in the examination paper are difficult to LEP learners and they perform poorly in Accounting. Joubert (2010) notes that LEP learners' poor language skills therefore hamper their ability to succeed academically.

The researcher learned that many of these participants had difficulty explaining that they battle with the interpretation of the language used in the question papers. The researcher derived that participants have difficulty understanding and interpreting the questions and at the same time to analyse the transactions. The researcher is of the opinion that although many LEP Accounting learners may sometimes know how to answer a question but fail to do so correctly because of the struggle to understand the concepts and language used in the question papers.

\subsection{Theme 2: Understanding Accounting Equation Concepts}

Most participants indicated that the Accounting concepts were not dealt with in the Accounting classroom and it is difficult for them to answer these concepts because they lack knowledge on these Accounting concepts. Some of these participants claimed that their teacher focuses on the calculations of the equation only and that it is their responsibility to learn the Accounting concepts on their own. Participant \#8, male: "We were not taught Accounting concepts, like the equation, we must do it on our own".

Many participants seemed to get somewhat confused with the Accounting concepts and provided answers which are not relevant to the given concept, namely the Accounting equation. The indication is that teachers do not thoroughly explain Accounting concepts to learners, with the result that learners are not able to explain a concept such as the Accounting equation in English. Participant \#23, female: "Accounting equation is the balancing of an accounts in Accounting, not explain the Accounting concepts them to us". Some participants indicated that they are able to explain concepts when the engage with their mother tongue, but when the need to do that in English they start struggling. Participant \#25, female: "It is easy for me to explain it in mother tongue to my teacher, eish not English".

A few participants gave answers which the researcher took as partly correct. They could not respond in detail. They mentioned only terms without providing a proper explanation or provided some examples which are relevant. In addition, a few participants said that they knew what the Accounting concepts meant, but that they did not know how to explain it in English. The researcher came to the conclusion that they may know the meaning of the concept, accounting equation, but that they did not have the English vocabulary to explain themselves adequately. They seemed frustrated by not being able to answer in English. Participant \#16, female: "It is the books for Accounting".

A few participants mentioned Assets, Owners Equity and Liability, but without any explanation. They seemed to lack confidence in their ability to use English when engaging with cognitive Accounting language. They could not furnish a correct answer for this concept. They seemed not to be able to find the vocabulary to express themselves properly. Participant \#28, female: 'Accounting is assets, owners' equity and liability $(A=O+L)$.

Interpretation: It seems as if Accounting concepts were not thoroughly explained to all learners by their teachers. It would therefore appear that these basic concepts may have been neglected by teachers and it 
could be assumed that learners were not provided with sufficient and appropriate application and extension exercises as part of the classroom and assessment practices.

Many of the incorrect responses made no sense to the researcher. It seems that these participants had difficulty in processing what they read to a meaningful answer. Sentence construction, as well as spelling, were very poor. Joubert (2010) asserts that LEP learners with a poor background in English skills experience greater difficulty with Accounting and thus need additional support to cope academically. Williams (2016) agrees that learners who are poor in English experience problems with reading and comprehension of words and symbols. In Grade 10, case studies are included in the syllabus of Accounting, and this has a negative impact on learners whose English reading skill is not adequately developed as they are not able to interpret and analyse the case studies to provide correct answers for these case studies. Their poor language skills therefore hamper their ability to succeed academically (Joubert, 2010). Accounting teachers are advised to promote reading and analysis of texts and should discourage learners from memorization without having an understanding of the concepts.

Only short phrases were given by participants. They did not seem to trust their language ability to venture into any elaboration. LEP learners need time for clarification and further explanation of the Accounting concepts by the teacher (Froschauer \& Bigelow, 2012:30). The researcher is of the opinion that LEP Accounting learners' understanding of concepts will assist them to engage with the more complex aspects of Accounting. Therefore, the inability of LEP Accounting learners to master more complex questions could be an indication that basic concepts were not properly addressed. It is the opinion of the researcher that the teachers do not highlight the differences between different concepts and their meaning.

\subsection{Theme 3: Year-End Adjustments Concepts}

Most participants attempted to explain the concept. From their responses one could glean that some learners have an idea, but that most seemed not to know either what it meant or how to explain it in English. Their answers were not relevant to the question at all. The researcher got the impression that some of these participants actually thought they answered correctly. It was either that, or they felt that they were obliged to answer, whether they provide a correct answer or not. Participant 23, female: "It is the preparation of the balance sheet and income statement".

Some participants seem to lack confidence when answering a question, either during assessment or in the teaching and learning classroom situation because they claim to be tense during any questioning process. They indicated that they then prefer not to take part in academic classroom communication because of lack of confidence. Participant \#2, male: “... feeling shy or insecure and it is really hard to try and follow the teacher in the classroom and not sure when answering the questions in the classroom to the teacher or classmates".

A few participants provided answers which the researcher took as partly correct. Most of these participants stated the basic answer only, but failed to explain and to elaborate on them. Participants seemed not to be interested to ensure that they explain their answers thoroughly. This demonstrated that the LEP Accounting learners are not capable of fully expressing or explaining their point of view to the Accounting teachers or other learners in class. Participant \#17, female: "It is a process of adjusting the entry or transaction at the end of the years".

Three participants did not respond to this question or even attempted to try to answer it. One could deduce that they did not know what the concept mean and therefore did not attempt any answer.

Interpretation: Writing logically constructed answers, sentence construction, as well as spelling seem to be the major problems of LEP Grade 10 Accounting learners. They would rather use short sentences, than to attempt a more elaborate answer. The result is that not enough information is provided to ensure that answers provided can be taken as correct. This seems a definite reason why these learners perform academically weaker. The researcher is of the view that participants who did not attempt to answer some of the posed questions, either did not understand the question or lacked the English language skills to formulate an answer. Lee (2009) and Banks (2012:1366), claim that using English within a cognitive academic surrounding creates problems for LEP learners in that they are unable to fully engage with the syllabus at hand. The researcher is of the opinion that LEP Accounting learners need to understand and explain basic concepts and terminology before engaging in Accounting applications in each topic

\section{SUMMARY AND CONCLUSION}

In South Africa, most schools and parents opt for English as the default language of learning, and this 
continued tendency should be seriously queried as it has a major effect on the academic performance of learners (also in Accounting but LEP Accounting struggle to do well when taught in English.The majority of South African learners use English as language of learning although it is not their mother tongue. The South African example clearly indicates that a language policy in favour of the use of English as language of learning does not guarantee higher levels of English proficiency and indicates that learners with poor English language skills experience difficulty with content subjects such as Accounting, and thus need a lot of support from their teachers.

The difficulty by LEP learners to communicate, poor language application, lack of vocabulary, and poor reading in the Accounting classroom are all challenges to the majority of LEP learners and prohibit them from giving their opinions and participating. There is often misunderstanding between learners and teachers in the classroom because of language barriers. When unable to prepare beforehand, learners are afraid to participate because they are not sure of their answers or of making mistakes in front of the teacher or their classmates, and also are afraid of being laughed at because of poor language skills and competence

In order to improve the language skills of LEP learners, it is recommended that the Accounting teacher must emphasise listening, speaking, reading, and writing skills in the Accounting classroom. This can be done by using the learners' centered approach teaching whereby learners read Accounting transactions, interpret and analyses them in their small group. Such engagement of using various activities gives learners an opportunity to participate and not only be an audience but practice listening, speaking, reading and writing skills. These four skills must be included when the Accounting teacher teaches Accounting in the classroom as a strategy to improve the English proficiency skills of LEP learners. The study recommends that the South Africa government should implement mother tongue education in South African schools, since their belief is that this will address the problem of LEP learners who struggle to perform well when they are not using their mother tongue for learning. The study recommended that learning is simplified if it moves from the concrete to the abstract. Therefore, it is recommended that good foundation must be built by the teachers at school and parents at home, so that learners understand the Accounting abstract concepts. The basic Accounting concepts and English terminology must be explained by the teachers and parents to the LEP Accounting learners

\section{REFERENCE LIST}

Ary, D., Jacobs, L. C., Razavieh, A. and Sorensen, C. (2009). Introduction to Research in Education (pp 426-427). Wadsworth: Engaged Publishing

BANKS, J.A. (2012). Encyclopaedia of Diversity in Education. California: SAGE Publication

FERREIRA, G. (2011). Teaching Life Sciences to English Second Language Learners: What do Teachers do? South African Journal Education, 31(10):102-113

FERRIS, D.R. (2009). Teaching College Writing to Diverse Student Populations.Michigan: University of Michigan Press

FROSCHAUER, L., \& BIGELOW, M.L. (2012). Rise and Shine: A Practical Guide for the Beginning Science Teacher. Arlington: NSTA Press

Hesse-Biber, S. N. and Leavy, P. (2011). The Practice of qualitative Research. (360-365). Singapore: SAGE Publication Inc

JOUBERT, J.A. (2010). Significant Predictors of Success and Non-Completion in First Year. PhD thesis. University of the Free State

LEE, J.L. (2009). Teachers Sense of efficiency in Teaching English Perceived English Language Proficiency, and Attitudes Towards the English Language: A Case Study of Korean Public Elementary School Teachers. PhD Thesis. Universityof Ohio State University.

MONYAI, S.C. (2010). Meeting the Challenges of Black English Second-Language South African Learners in Ex-Model C Primary Schools. M.Ed. dissertation. Pretoria: University of Pretoria.

WRIGHT, A.W., \& BILICA, K. (2007). Instructional Tools to Probe Biology Students'Prior Understanding. American Biology Teacher, 69:1-5 